\title{
Hydrogeologic Framework and Ground-Water Resources at Seymour Johnson Air Force Base, North Carolina
}

By Alex P. Cardinell and Stephen S. Howe

U.S. GEOLOGICAL SURVEY

Open-File Report 96-581

Prepared in cooperation with the

U.S. Environmental Protection Agency

Region IV

Atlanta, Georgia

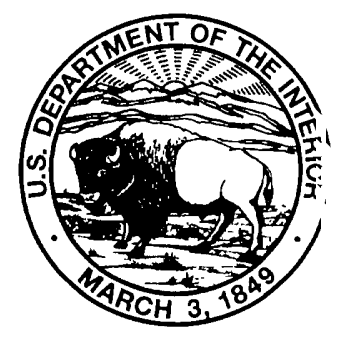




\title{
U.S. DEPARTMENT OF THE INTERIOR BRUCE BABBITT, Secretary
}

\author{
U.S. GEOLOGICAL SURVEY
}

Gordon P. Eaton, Director

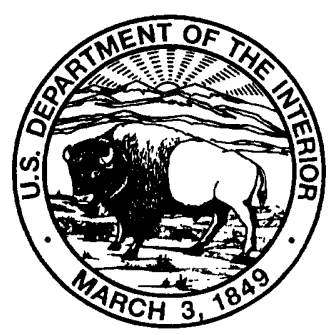

The use of firm, trade, and brand names in this report is for identification purposes only and does not constitute endorsement by the U.S. Geological Survey.

For additional information write to:

District Chief

U.S. Geological Survey

3916 Sunset Ridge Road

Raleigh, NC 27607
Copies of this report can be purchased from:

U.S. Geological Survey

Branch of Information Services

Box 25286, Federal Center

Denver, CO 80225 


\section{CONTENTS}

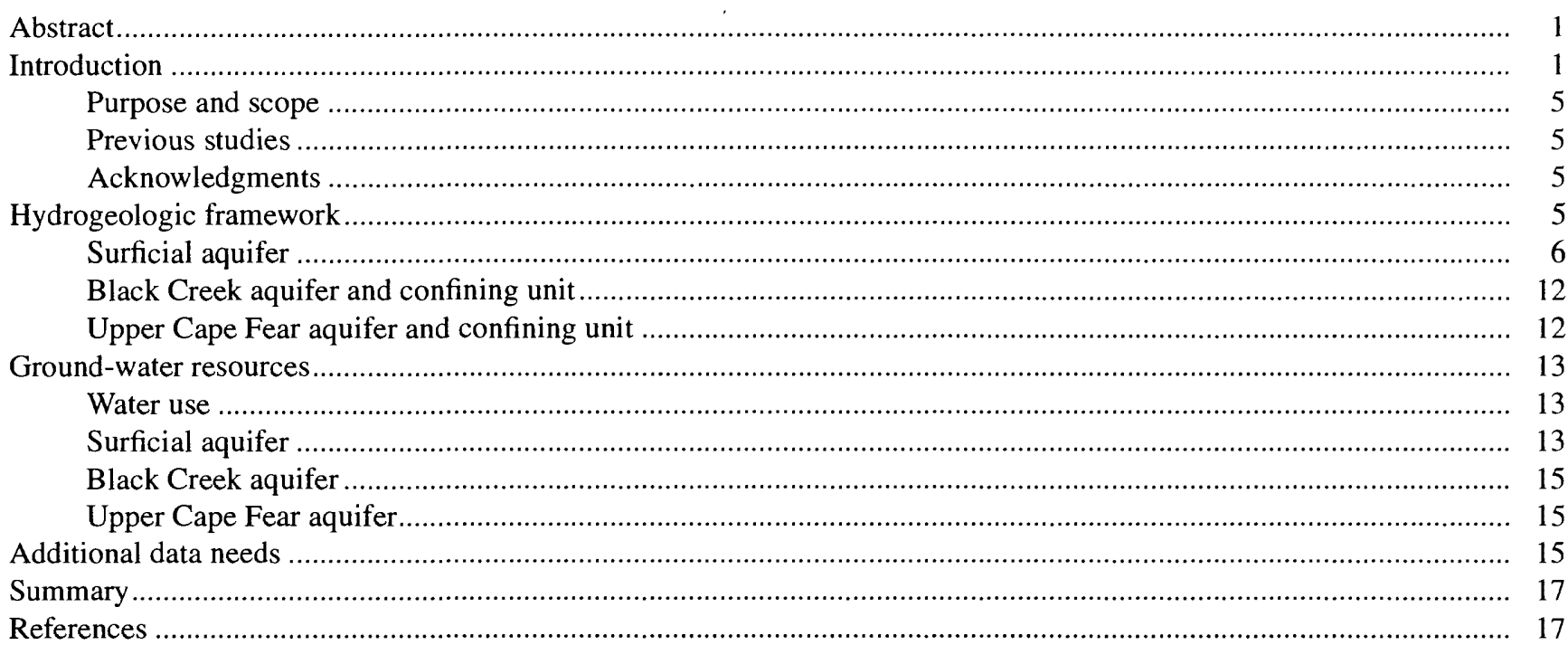

\section{FIGURES}

1.-3. Maps showing:

1. Location of Seymour Johnson Air Force Base, North Carolina........................................................... 2

2. Subregions of Coastal Plain physiographic province of North Carolina .................................................... 3

3. Locations of monitoring wells, water-supply wells, irrigation wells, and stratigraphic test wells at Seymour Johnson Air Force Base

4. Generalized relation between geologic and hydrogeologic units in the North Carolina Coastal Plain .................. 7

5. Map showing locations of hydrogeologic sections at Seymour Johnson Air Force Base.................................... 8

6. Hydrogeologic section A-A' at Seymour Johnson Air Force Base............................................................

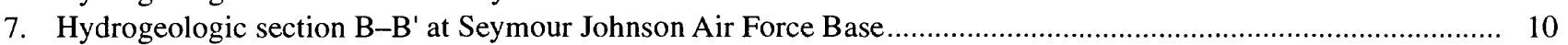

8. Water-level surface map for surficial aquifer at Seymour Johnson Air Force Base, June-July 1996...................... 14

9. Estimated altitude of top of Black Creek aquifer in northeast part of Seymour Johnson Air Force Base................. 16

\section{TABLES}

1. Records of selected water-supply and stratigraphic test wells in the Seymour Johnson Air Force Base area

2. Records of selected monitoring wells in the Seymour Johnson Air Force Base area .....................................20

3. Summary of aquifer and confining unit hydrogeologic data. 
CONVERSION FACTORS, VERTICAL DATUM, DEFINITIONS, ABBREVIATIONS, AND ACRONYMS

\begin{tabular}{rcl}
\hline Multiply & by & To obtain \\
\hline & Length & \\
inch (in.) & 25.4 & millimeter \\
foot (ft) & 0.3048 & meter \\
foot per mile (ft/mi) & 0.1894 & meter per kilometer \\
mile (mi) & 1.609 & kilometer \\
& Area & \\
acre & 4,047 & square meter \\
& Flow & \\
gallon per minute (gal/min) & 0.06309 & liter per second \\
\hline
\end{tabular}

Sea Level: In this report, "sea level" refers to the National Geodetic Vertical Datum of 1929 (NGVD of 1929) - a geodetic datum derived from a general adjustment of the firstorder level nets of both the United States and Canada, formerly called "Sea Level Datum of 1929."

\section{Definitions-}

Altitude: In this report, altitude refers to the distance above or below sea level.

North Carolina State Plane Coordinate System: Several illustrations in this report are referenced to the North Carolina State Plane Coordinate System. This reference system was established by the U.S. Coastal Geodetic Survey in 1933 for use in defining locations in plane-rectangular Cartesian coordinates.

\section{Abbreviations and Acronyms:}

$\begin{array}{ll}\text { AOC } & \text { Area of concern } \\ \text { COE } & \text { U.S. Army Corps of Engineers } \\ \text { EPA } & \text { U.S. Environmental Protection Agency } \\ \text { in } / \mathrm{hr} & \text { inch per hour } \\ \text { POL } & \text { petroleum, oil, and lubricant } \\ \text { RASA } & \text { Regional Aquifer-System Analysis } \\ \text { RCRA } & \text { Resource Conservation and Recovery Act } \\ \text { SAC } & \text { Strategic Air Command } \\ \text { SJAFB } & \text { Seymour Johnson Air Force Base } \\ \text { USGS } & \text { U.S. Geological Survey }\end{array}$




\title{
HYDROGEOLOGIC FRAMEWORK AND GROUND- WATER RESOURCES AT SEYMOUR JOHNSON AIR FORCE BASE, NORTH CAROLINA
}

\author{
By Alex P. Cardinell and Stephen S. Howe
}

\section{ABSTRACT}

A preliminary hydrogeologic framework of the Seymour Johnson Air Force Base was constructed from published data, available well data, and reports from Air Base files, City of Goldsboro and Wayne County records, and North Carolina Geological Survey files. Borehole geophysical logs were run in selected wells; and the surficial, Black Creek, and upper Cape Fear aquifers were mapped.

Results indicate that the surficial aquifer appears to have the greatest lateral variability of clay units and aquifer material of the three aquifers. A surficial aquifer water-level surface map, constructed from selected monitoring wells screened exclusively in the surficial aquifer, indicates the general direction of ground-water movement in this mostly unconfined aquifer is toward the Neuse River and Stoney Creek. However, water-level gradient data from a few sites in the surficial aquifer did not reflect this trend, and there are insufficient hydrologic and hydrogeologic data to determine the cause of these few anomalous measurements.

The Black Creek aquifer underlies the surficial aquifer and is believed to underlie most of Wayne County, including the Air Base where the aquifer and overlying confining unit are estimated from well $\log$ data to be as much as 100 feet thick. The Black Creek confining unit ranges in thickness from less that 8 feet to more than 20 feet. There are currently no accessible wells screened exclusively in the Black Creek aquifer from which to measure water levels.

The upper Cape Fear aquifer and confining unit are generally found at depths greater than 80 feet below land surface at the Air Base, and are estimated to be as much as 70 feet thick.

Hydrologic and hydrogeologic data are insufficient to determine localized surficial aquifer hydrogeology, ground-water movement at several sites, or hydraulic head differences between the three aquifers.

\section{INTRODUCTION}

Seymour Johnson Air Force Base (SJAFB) is located in Wayne County, North Carolina, about 60 miles southeast of Raleigh (fig. 1). SJAFB covers 3,216 acres and is bounded by the city of Goldsboro to the north, the Neuse River to the southwest, Stoney Creek to the northwest, and various developmental areas to the east and south.

Wayne County and SJAFB are in the inner Coastal Plain region of the Coastal Plain physiographic province (fig. 2) where the upland surface is flat and slopes toward the southeast. Maximum relief in the county occurs in and adjacent to the stream valleys of the major rivers that flow in a southeasterly direction. At the Cliffs of the Neuse State Park south of SJAFB, the relief along the Neuse River is about 100 feet ( $\mathrm{ft}$ ). The larger streams in the county meander and have developed flat, wide flood plains.

SJAFB was commissioned in June 1942. During World War II, the Air Base housed a technical school and a provisional overseas replacement training center, 


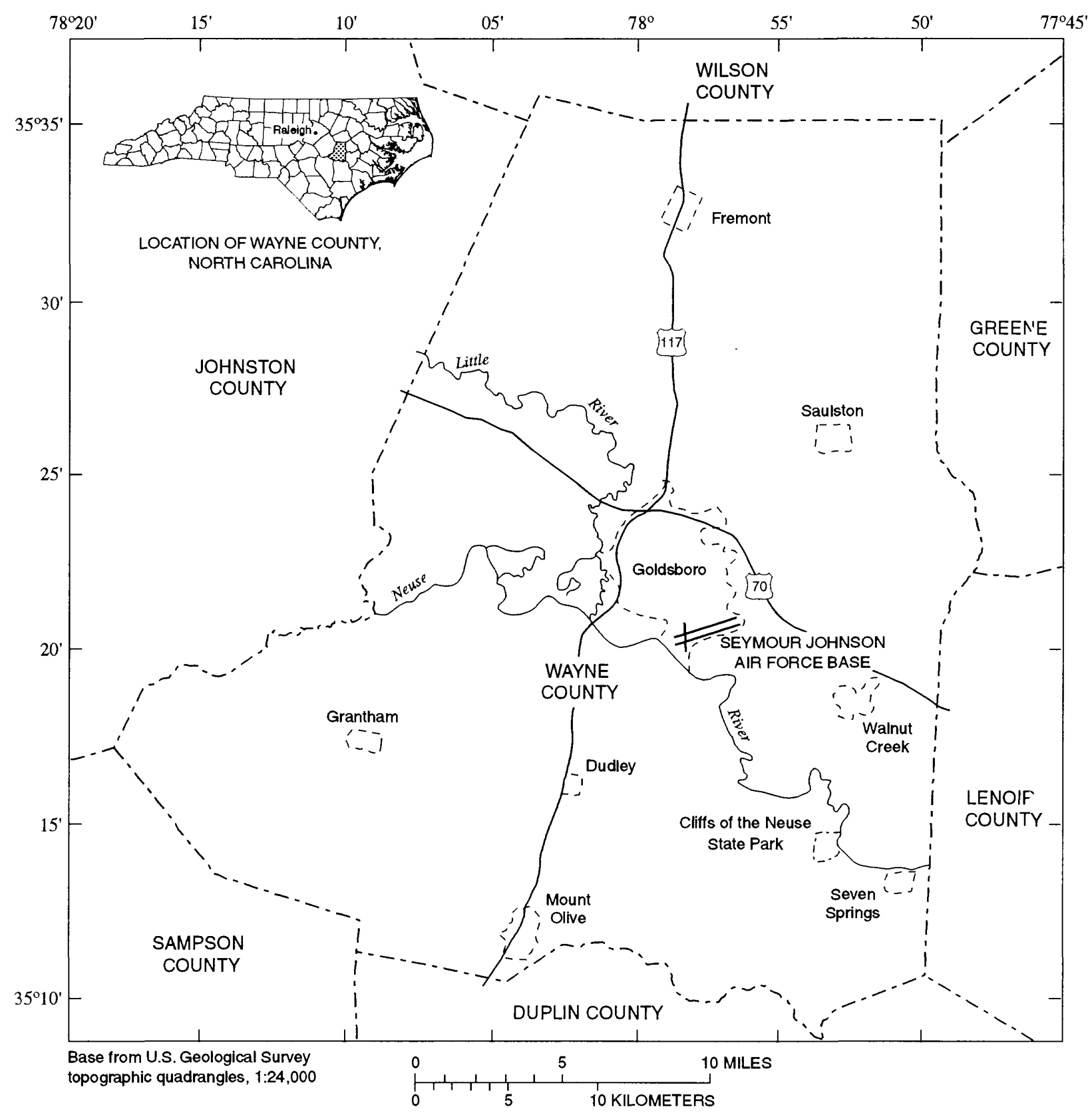

Figure 1. Location of Seymour Johnson Air Force Base, North Carolina.

and was the home of the 326th Fighter Group. The Air Base was deactivated between 1946 and 1952. Since 1956, SJAFB has housed several fighter wings, bomber wings, and bomber and tanker squadrons. At the present time, the primary command at SJAFB is the Air Combat Command's 4th Fighter Wing.

Site assessment and site characterization studies have been conducted by SJAFB to address environmental problems related to spills and leaks of petroleum fuels from above-ground and under $\xi^{*}$ ound storage tanks at several locations on the Air Base. In several cases SJAFB personnel have constructed a series of recovery systems to remove petroleum fuels (primarily JP-4 and JP-5) from ground water at these sites. Two sites where recovery systems have been installed are the Petroleum, Oil, and Lubricant (POL) storage area (Sites SD-02 [RCRA Site No. AO 2 F], SD-03 [RCRA Site No. AOC G], and ST-05 [RCRA 


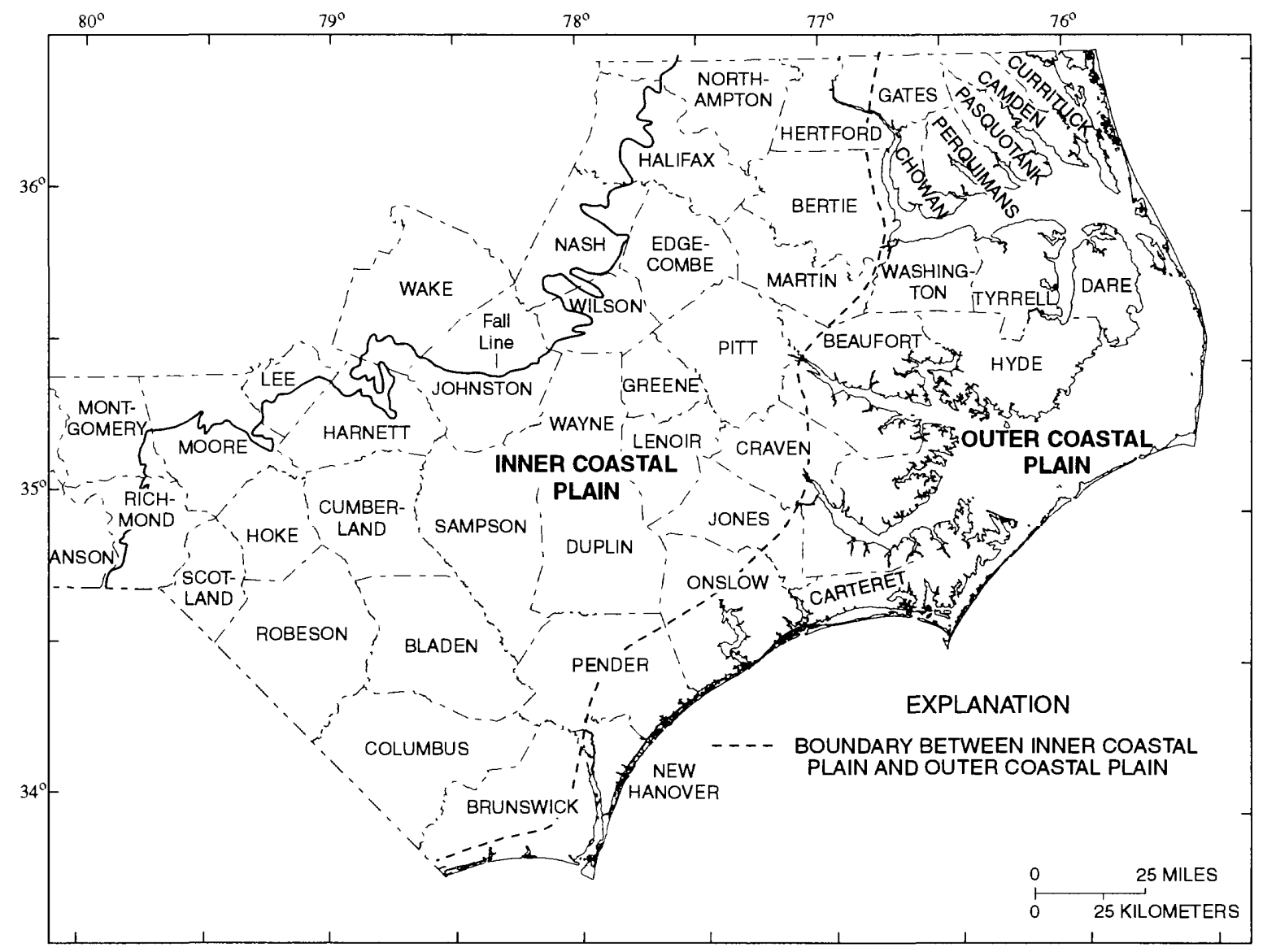

Figure 2. Subregions of Coastal Plain physiographic province of North Carolina.

Site No. AOC J]) and the Strategic Air Command (SAC) Fuel Hydrant System (SS-12) (fig. 3). The recovery systems at these sites have not recovered significant amounts of JP-4 fuel estimated to be in the subsurface (IMS, 1995).

A review of the results of studies conducted at the POL and SAC sites indicates that several clusters of shallow monitoring wells (most of these wells are open to the water table) have been placed at these sites. Lithologic data were collected from well borings at these sites; samples generally consisted of split-spoon sediment samples collected at 5-ft intervals. However, these data now appear to have been insufficient to map the near-surface hydrogeology. This lack of sufficient information on the shallow hydrogeologic framework makes it difficult to determine if recovery systems were properly placed in relation to the hydrogeologic setting. Improving the understanding of the sitespecific, near-surface hydrogeology in sufficient detail is important in order to evaluate current recovery systems or the design of any new fuel recovery system.
There also is a lack of sufficient hydrogeologic data to delineate the deeper hydrogeologic units. Available data from the water-supply wells that were constructed in the 1940's and 1950's consist of drillers' logs. These well logs are not of sufficient detail to accurately map the different aquifers and confining units that underlie the Air Base. These wells from the 1940's and 1950's are now plugged and abandoned and are not accessible for geophysical logging. Most of these deeper wells were in the southern corner of the Air Base, and these well data do not include geophysical or lithologic well logs.

Consequently, Region IV U.S. Environmental Protection Agency (EPA) has requested the U.S. Geological Survey (USGS) to conduct a preliminary update of the hydrogeologic framework of the Air Base. The USGS used a combination of existing data and newly acquired geophysical-borehole logs and water-level measurements from selected shallow and deep wells on the Air Base (fig. 3; tables 1 and 2, p. 19-21). These data provide a more detailed description of the near-surface hydrogeology and 


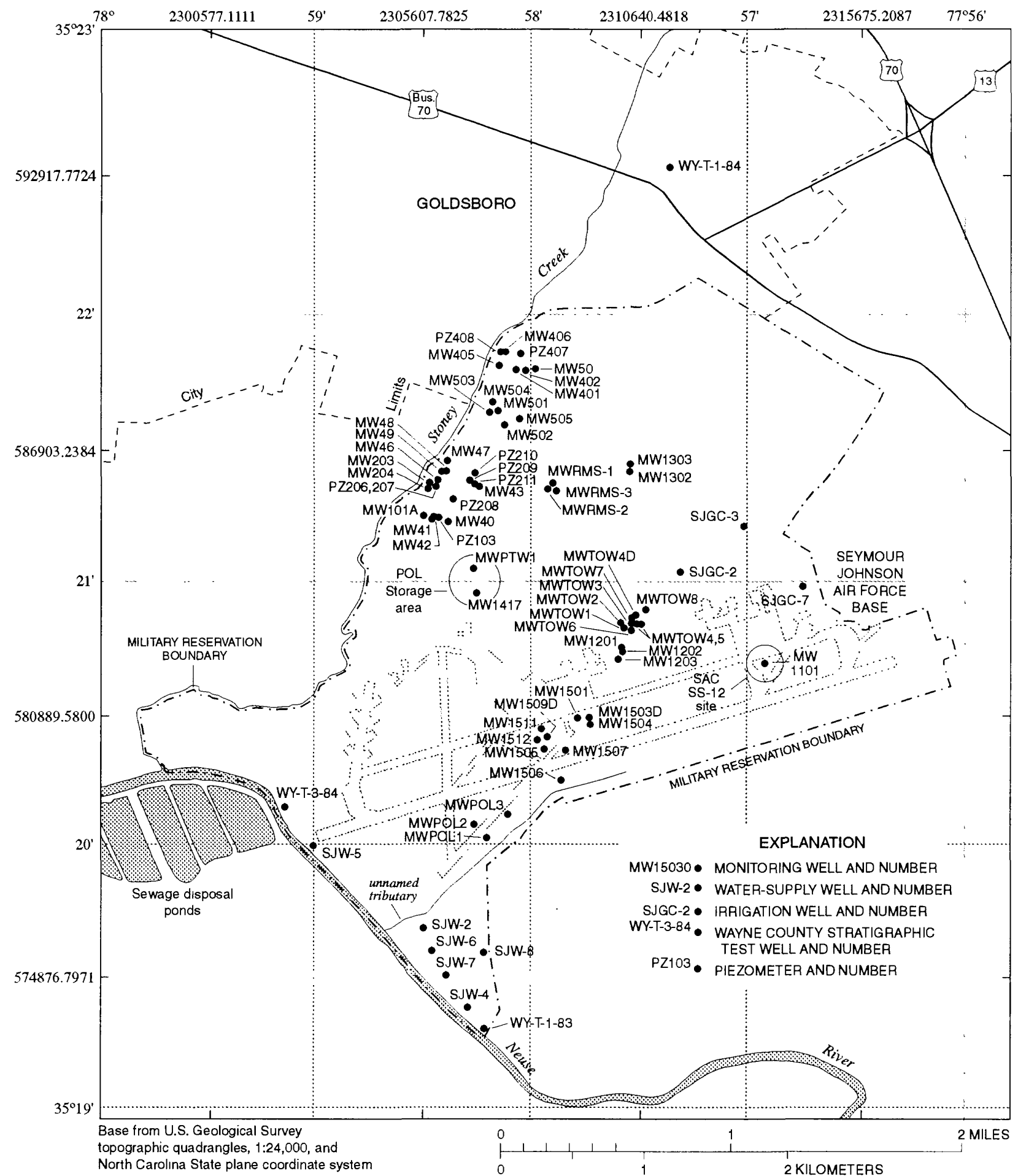

Figure 3. Locations of monitoring wells, water-supply wells, irrigation wells, and stratigraphic test wells at Seymour Johnson Air Force Base, North Carolina. 
underlying aquifer system. These hydrogeologic data could be used to evaluate proposed work plans for future fuel recovery systems and for work at other solid-waste management units on the Air Base.

\section{Purpose and Scope}

This report presents a hydrogeologic framework and an assessment of ground-water resources at SJAFB to guide subsequent phases of the environmental and hydrologic studies. The data reviewed include well records from the Air Base, Wayne County, the City of Goldsboro, the USGS, the North Carolina Geological Survey (NCGS), and from other publications. This information includes well logs, well-construction and pumping data, historical water-level measurements, and some water-use data. The data from these sources are from the early 1940's to the early 1990's.

The scope of work at SJAFB included an inventory of available hydrogeologic information from the Air Base water-supply wells and the collection of geophysical well logs from selected accessible golf course wells on the Base, at selected shallow monitoring wells at the POL and SAC sites, and at other sites on the Base. Water-level measurements also were taken at selected monitoring wells screened in the surficial aquifer.

\section{Previous Studies}

Hydrogeologic studies since the 1960's in and around Wayne County range from multi-county reconnaissance studies to detailed investigations of county and multi-county areas. A report by Brown and others (1972) included Wayne County as part of a multi-state investigation of Coastal Plain sediments. Winner and Coble (1996) presented a hydrogeologic framework of the North Carolina Coastal Plain.

The results of multi-county hydrogeologic studies including Wayne County are reported in Pusey (1960), Winner and Lyke (1987), and Winner and Coble (1996). Investigations of nearby counties include a report on Wilson County by Winner (1976). Reports resulting from the Winner and Lyke (1987) study of the central Coastal Plain include an altitude map of the basement surface (Lyke and Winner, 1986), which is the lower boundary of the hydrogeologic system, and a report describing the historical ground-water pumpage from the aquifers in the Cretaceous rocks (Winner and
Lyke, 1986), and the relation of pumpage to an overall water-level decline in these aquifers from 1900 to 1980.

\section{Acknowledgments}

Mr. Robert Pope, Region IV U.S.

Environmental Protection Agency, served as the principal liaison between the environmental staff at Seymour Johnson Air Force Base and the U.S. Geological Survey. Mr. Ralph Epperson-Schaeffer and Mr. Greg Ditzler of the Environmental Branch, Seymour Johnson Air Force Base, provided access to well-record data and to sites on the Base. Mr. John Nickerson, North Carolina Geological Survey, Raleigh, N.C., provided well records and geophysical well logs from selected wells located throughout Wayne and Lenoir Counties.

\section{HYDROGEOLOGIC FRAMEWORK}

In order to develop a hydrogeologic framework for use in defining the movement of ground water throughout the study area, the concept of hydrogeologic units was adopted. This concept is similar to the concept of "hydrostratigraphic units" proposed by Maxey (1964) to describe "bodies of rock with considerable lateral extent that compose a geologic framework for a reasonably distinct hydrologic system." The hydrogeologic system used in this report is similar to that identified in the North Carolina Regional Aquifer-System Analysis (RASA) program (Winner and Coble, 1996), in which Coastal Plain sediments are organized into a system that meets both geologic and hydrologic criteria.

The unconsolidated aquifer system of the inner Coastal Plain beneath Wayne County and SJAFB is made up of a number of imperfectly connected sand bodies, any one of which may have only local extent and, for short periods of time, may act under stress as a distinct hydraulic unit. On a regional scale, however, these permeable beds can be grouped into major aquifer units based on (1) significant differences in hydraulic head across confining units that separate aquifers, (2) evidence of widespread lateral transmission of drawdown effects, thus indicating lateral extent of permeability, and (3) water-quality similarities within an aquifer and differences in water quality between aquifers separated by confining units. 
Confining units consist of individual beds or groups of beds of clay, silty clay, sandy clay, silt, and fine sand. A confining unit, by definition, occurs only where the underlying aquifer is present. When an aquifer pinches out, the confining unit can merge with the underlying confining unit. Like the aquifers they overlie and underlie and thus confine, regional confining units also are imperfectly connected bodies. Some confining units can be traced long distances, although any given confining unit may not be stratigraphically equivalent everywhere. However, an important consideration is the demonstrated hydrologic effect of the confinement on the major aquifers.

Criteria used to map hydrogeologic units identified in this report include the use of existing lithologic and borehole-geophysical data; hydraulic properties of rocks such as porosity, hydraulic conductivity, or storage coefficient; and the mapping of hydraulically connected permeable units. Although aquifer boundaries may coincide with or parallel those of chronologic or lithologic units in local areas, they are not usually everywhere constrained within these limits. This is especially true in the unconsolidated deposits of the Coastal Plain.

The data used to develop the hydrogeologic framework at SJAFB included well data from approximately 62 shallow monitoring wells and 9 water-supply and irrigation wells on the Base, and 3 Wayne County wells (fig. 3). Records at these wells and selected other wells are presented in tables 1 and 2.

Delineation of the hydrogeologic units at SJAFB was accomplished by well correlations of lithologic units using the standard single-point electric log (selfpotential and resistance curves) and the natural gamma-ray radiation $\log$. The method of correlation used was to superimpose lithologic logs from adjacent wells onto the geophysical log traces to determine the continuity of sediments from well to well.

Chronostratigraphic units identified by Brown and others (1972) were used to guide correlations in the eastern part of the study area where well coverage was less dense.

Aquifers of the North Carolina Coastal Plain (fig. 4) consist of permeable sand or limestone beds intermixed with less permeable confining units composed of clay or silt beds. The aquifers are distinguished from one another based on lithologicand geophysical-log correlations, and water-level and water-quality differences caused by the effect of areally extensive clay and silt confining units, which separate the aquifers. These aquifers and confining units are generally characterized as (1) overlying crystalline basement rocks, (2) having a dip to the east-southeast, (3) having a general thickening of beds toward th? eastsoutheast, (4) having an increase in the number of individual beds toward the east, and (5) having traceable regional continuity.

Two hydrogeologic sections (fig. 5) were constructed in part of SJAFB/Goldsboro/Wayne. County from available geophysical-log data, lith ologic data, and well-construction data (A-A', B-B', figs. 6 and 7 ). Aquifers and confining units were delineated on these hydrogeologic sections on the basis of borehole geophysical logs and related data. Section A-A' trends to the southeast in the direction of dip, while se tion B-B' trends to the northeast, almost perpendicular to section A-A'.

Aquifers in the Coastal Plain have been divided into two general systems-the aquifers in rocks of Quaternary and Tertiary age and the aquifers in rocks of Cretaceous age. According to Eimers and other: (1990), the SJAFB/Goldsboro/Wayne County area contains two principal aquifers of Cretaceous ag - - the Black Creek and the upper Cape Fear-overlain by a surficial aquifer containing sediments that range in age from Quaternary to Tertiary.

\section{Surficial Aquifer}

The surficial aquifer is not restricted to a geologic unit in terms of either age or lithology. Because the origin and age of sediments composing the aquifer are not the same everywhere, it is neces ary to describe in broad terms the various rock units of the aquifer as they occur in several parts of the Coastal Plain, including Wayne County.

In the western part of the Coastal Plain, sediments composing the surficial aquifer are coarser and more poorly sorted than those in the eastern part of the Coastal Plain. No attempt has been made to assign formal names to these sediments. They are generally described as Pleistocene terraces or simply terrace deposits. Where present, these sediments lie unconformably on rocks of Cretaceous to Mioce ne age and commonly range in thickness from a few feet to as much as $30 \mathrm{ft}$. 


\begin{tabular}{|c|c|c|c|}
\hline \multicolumn{3}{|c|}{ Geologic units } & \multirow{2}{*}{$\begin{array}{l}\text { Hydrogeologic units } \\
\text { Aquifer and confining unit }\end{array}$} \\
\hline System & Series & Formation & \\
\hline \multirow{3}{*}{ Quaternary } & Holocene & Undifferentiated & \multirow{2}{*}{ Surficial aquifer } \\
\hline & \multirow{2}{*}{ Pleistocene } & Flanner Beach & \\
\hline & & James City & Yorktown confining unit \\
\hline \multirow{9}{*}{ Tertiary } & \multirow{2}{*}{ Pliocene } & \multirow{2}{*}{ Yorktown } & Yorktown aquifer \\
\hline & & & \multirow{2}{*}{$\begin{array}{l}\text { Pungo River confining unit } \\
\text { Pungo River aquifer }\end{array}$} \\
\hline & \multirow{2}{*}{ Miocene } & \multirow{2}{*}{ Pungo River } & \\
\hline & & & \multirow{2}{*}{$\begin{array}{l}\text { Upper Castle Hayne confining unit } \\
\text { Upper Castle Hayne aquifer }\end{array}$} \\
\hline & \multirow{2}{*}{ Oligocene } & \multirow{2}{*}{ River Bend } & \\
\hline & & & \multirow{2}{*}{$\begin{array}{l}\text { Lower Castle Hayne confining unit } \\
\text { Lower Castle Hayne aquifer }\end{array}$} \\
\hline & \multirow{2}{*}{ Eocene } & \multirow{2}{*}{$\begin{array}{l}\text { Castle Hayne } \\
\text { Limestone }\end{array}$} & \\
\hline & & & Beaufort confining unit \\
\hline & Paleocene & Beaufort & Beaufort aquifer \\
\hline \multirow{4}{*}{ Cretaceous } & \multirow{4}{*}{$\begin{array}{c}\text { Upper } \\
\text { Cretaceous }\end{array}$} & Peedee & $\begin{array}{c}\text { Peedee confining unit } \\
\text { Peedee aquifer }\end{array}$ \\
\hline & & $\begin{array}{l}\text { Black Creek and } \\
\text { Middendorf }\end{array}$ & $\begin{array}{l}\text { Black Creek confining unit } \\
\text { Black Creek aquifer }\end{array}$ \\
\hline & & \multirow{2}{*}{ Cape Fear } & $\begin{array}{l}\text { Upper Cape Fear confining unit } \\
\text { Upper Cape Fear aquifer }\end{array}$ \\
\hline & & & $\begin{array}{l}\text { Lower Cape Fear confining unit } \\
\text { Lower Cape Fear aquifer }\end{array}$ \\
\hline & & & rocks \\
\hline
\end{tabular}

Figure 4. Generalized relation between geologic and hydrogeologic units in the North Carolina Coastal Plain (Winner and Coble, 1996). 


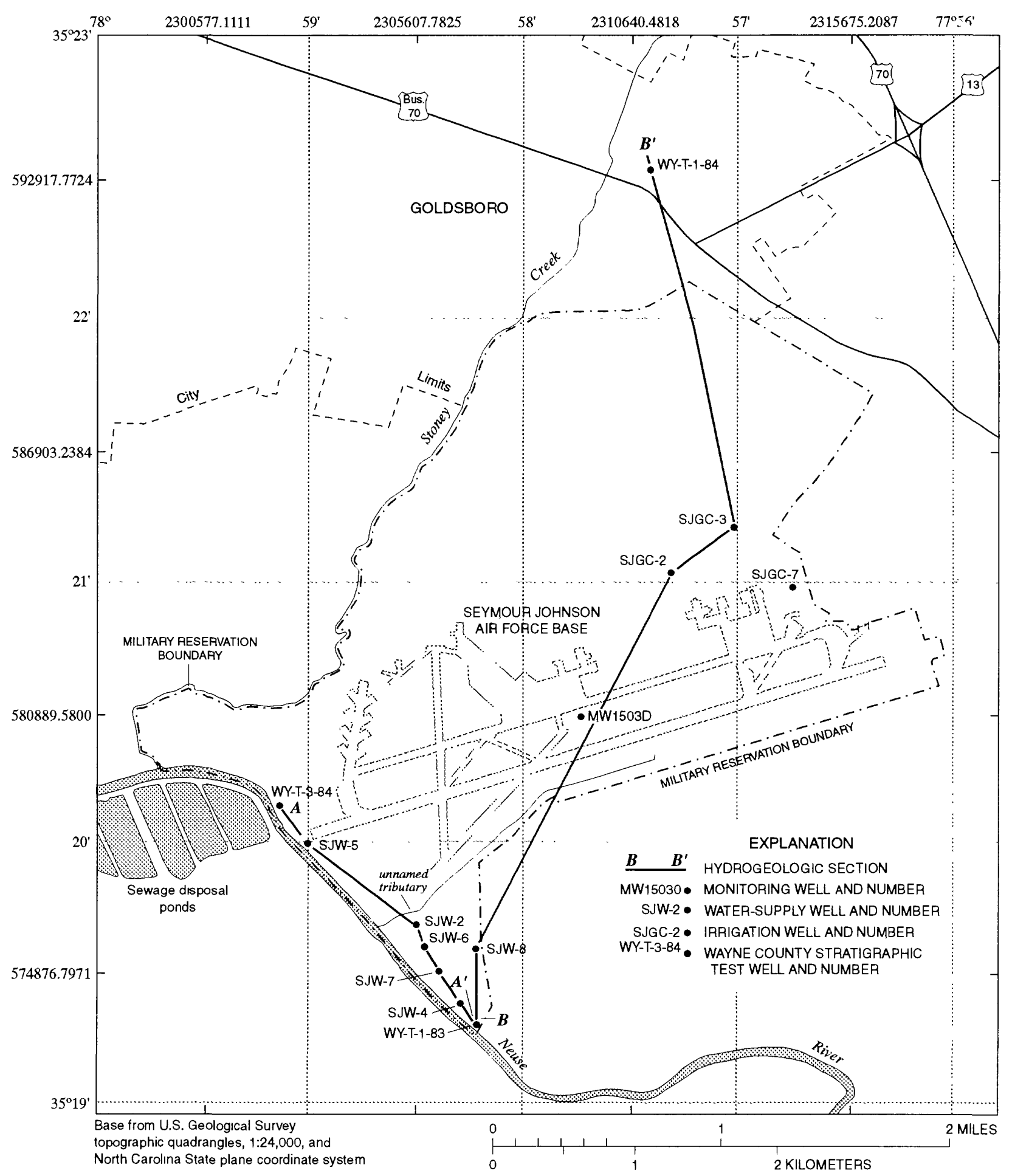

Figure 5. Locations of hydrogeologic sections at Seymour Johnson Air Force Base, North Carolina. 


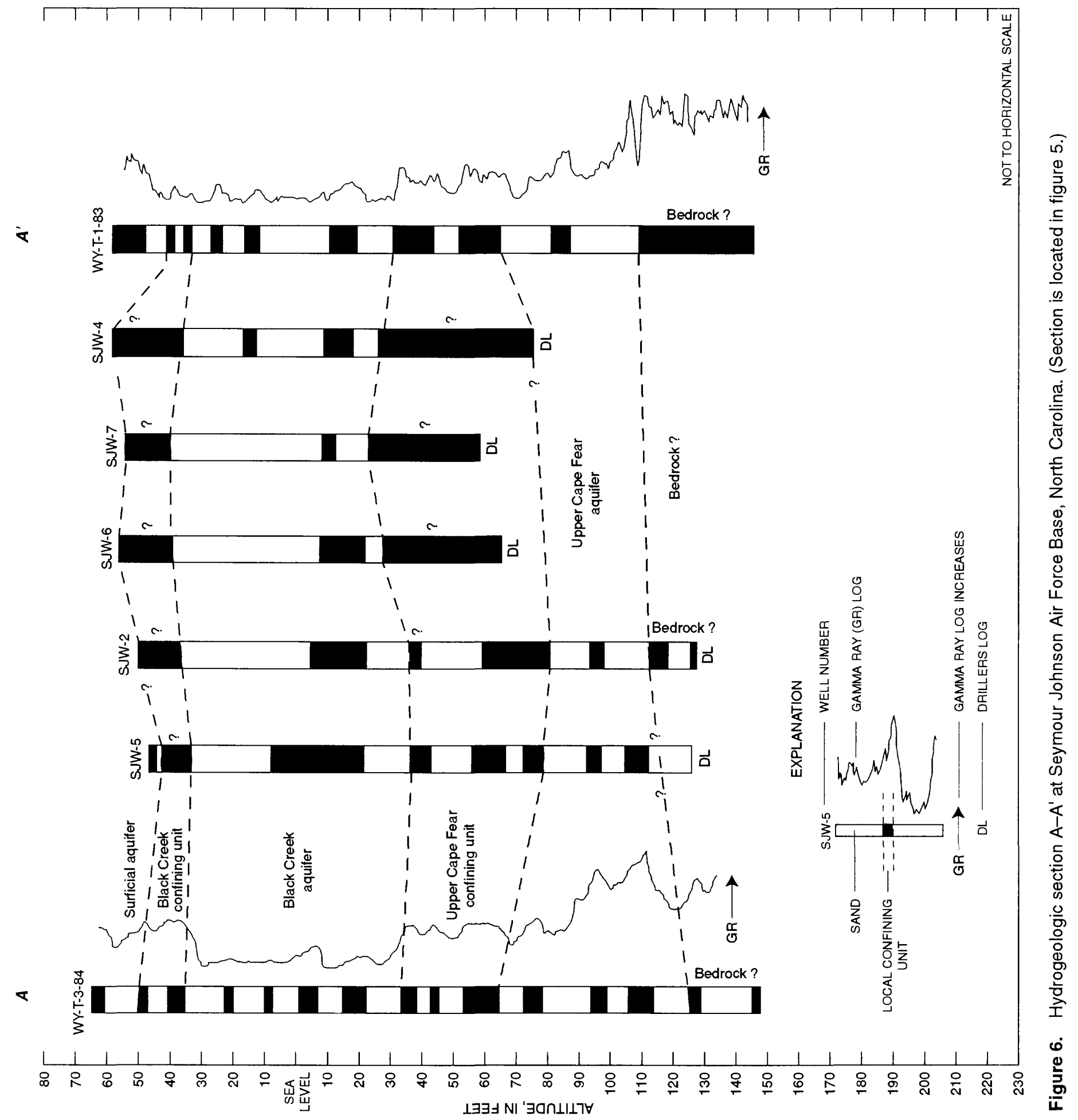

Hydrogeologic Framework 9 


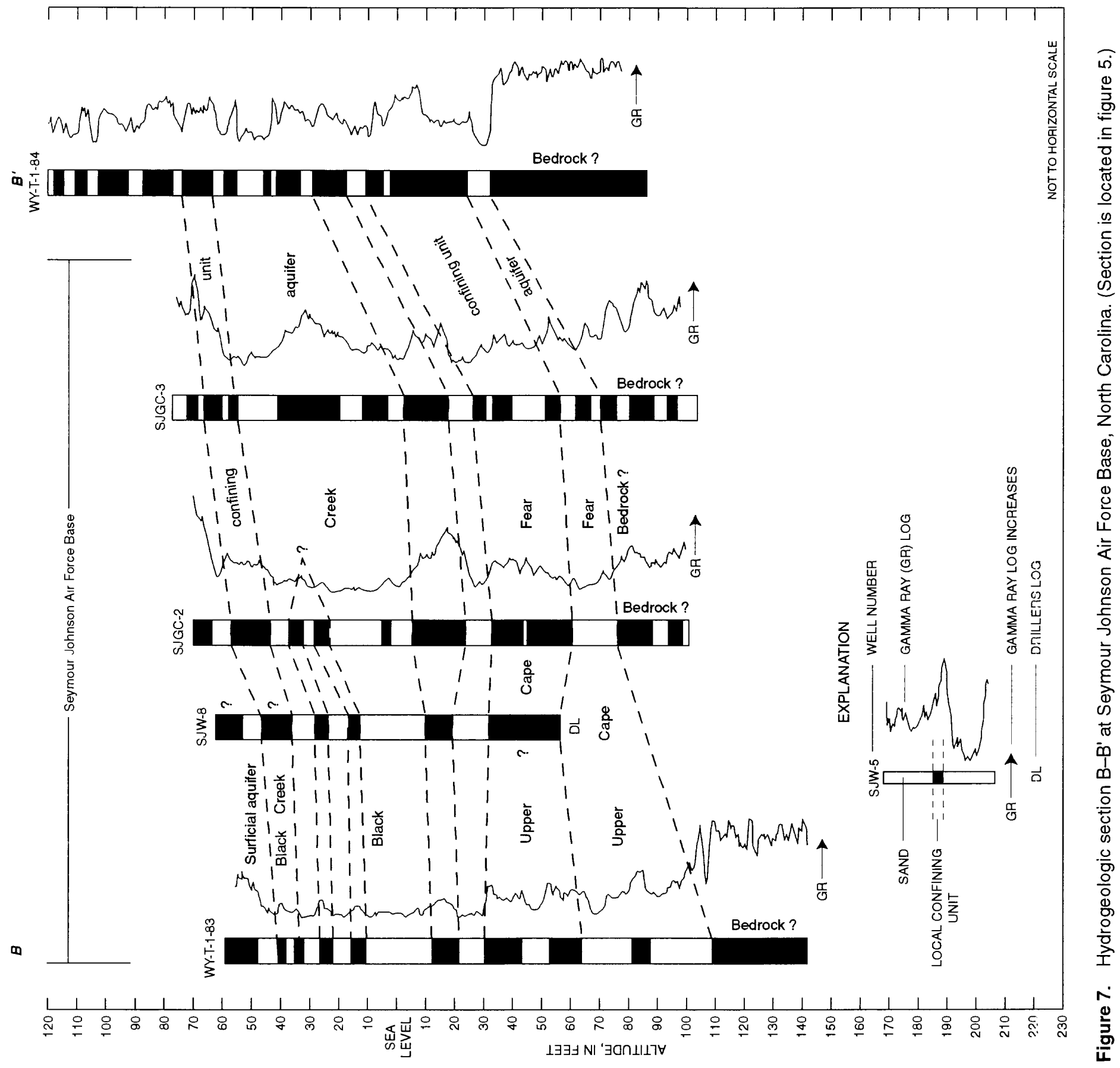


In Wayne County, the surficial aquifer includes surficial sand of post-Pliocene age that covers upland areas to depths of as much as $80 \mathrm{ft}$. Surficial sands may be $20 \mathrm{ft}$ thick or less in the lowland areas and are reported to be less than $40 \mathrm{ft}$ elsewhere in the county. At SJAFB, the surficial aquifer appears to be between 10 and $20 \mathrm{ft}$ thick (figs. 6 and 7), with the thicker sections in the upland areas and the thinner sections near the Neuse River. The Black Creek confining unit underlies the surficial aquifer at SJAFB.

Infiltration from rainfall is the main source of recharge to the Coastal Plain aquifer system. The surficial aquifer is the first unit to receive this recharge; it transmits water laterally to streams and serves as a source for water that recharges deeper aquifers.

Recharge to the surficial aquifer depends on how rapidly rainfall can infiltrate into the aquifer. As noted earlier, the lithology and thickness of the aquifer are not uniform in either composition or thickness. Recharge rates depend on the capacity of the soils formed from the various rock materials to allow water to move downward through the unsaturated zone.

Evaluation of relative recharge rates can be estimated for the infiltration capacities of the various soil associations delineated by the U.S. Natural Resources Conservation Service (formerly the Soil Conservation Service). Associations having good to moderate content and permeability were identified on the General Soil Map of North Carolina (Tant and others, 1974) and arranged as groups having good, moderate, or poor infiltration capacity. Soils in the northern half of Wayne County, including SJAFB, are considered to have good infiltration capacity and are mostly well-drained to very well-drained sandy soil and sandy loam. However, some soils in this area contain significant amounts of sand with soil permeabilities of 2 to 20 inches per hour (in/hr) that may exceed $20 \mathrm{in} / \mathrm{hr}$ in some areas (Winner and Coble, 1996, fig. 11). The soils in the southern half of Wayne County have a good infiltration capacity. This mostly well-drained to very well-drained sandy soil and sandy loam includes some soils containing significant amounts of clay with soil permeabilities of 2 to $20 \mathrm{in} / \mathrm{hr}$ (Winner and Coble, 1996, fig. 11).

Estimates of hydraulic conductivity and average percentage of permeable material in the surficial aquifer are presented in table 3 . Winner and Coble (1996, supplemental data, p. 101-104) report the percentage of permeable material in the surficial aquifer in Wayne County to vary from 58 percent to 90 percent in seven well borings. The aquifer here consists of poorly sorted fluvial material, which helps to explain the variability of sand content at these seven boring sites.

Table 3. Summary of aquifer and confining unit hydrogeologic data

[SJAFB, Seymour Johnson Air Force Base; ft/d, feet per day; <, less than; -, no data]

\begin{tabular}{|c|c|c|c|c|}
\hline $\begin{array}{l}\text { North Carolina } \\
\text { Coastal Plain } \\
\text { aquifers and } \\
\text { confining units }\end{array}$ & $\begin{array}{c}\text { Average percentage } \\
\text { of permeable } \\
\text { materlal in } \\
\text { North Carollna } \\
\text { Coastal Plain }\end{array}$ & $\begin{array}{c}\text { Average percentage } \\
\text { of permeable } \\
\text { material In } \\
\text { Wayne County/ } \\
\text { SJAFB area } 2\end{array}$ & $\begin{array}{l}\text { Average estimated } \\
\text { hydraulic } \\
\text { conductivity in } \\
\text { Coastal Plain } \\
(\mathrm{ft} / \mathrm{d})^{1}\end{array}$ & $\begin{array}{l}\text { Average estimated } \\
\text { hydraulic } \\
\text { conductivity in } \\
\text { Wayne County/ } \\
\text { SJAFB area } \\
\text { (ft/d) }{ }^{2}\end{array}$ \\
\hline Surficial aquifer & 79 & 80 & 29 & 26 \\
\hline $\begin{array}{l}\text { Black Creek } \\
\text { confining unit }\end{array}$ & 16 & $<14$ & - & - \\
\hline $\begin{array}{l}\text { Black Creek } \\
\text { aquifer }\end{array}$ & 59 & 61 & 28 & 26 \\
\hline $\begin{array}{l}\text { Upper Cape Fear } \\
\text { confining unit }\end{array}$ & 18 & $<12$ & - & - \\
\hline $\begin{array}{l}\text { Upper Cape Fear } \\
\text { aquifer }\end{array}$ & 62 & 47 & 30 & 27 \\
\hline
\end{tabular}

\footnotetext{
${ }^{1}$ Winner and Coble, 1996 (table 4, p. 17).

${ }^{2}$ Winner and Coble, 1996 (supplemental data, p. 101-104).
} 


\section{Black Creek Aquifer and Confining Unit}

Winner and Coble (1996) indicate that the Black Creek aquifer consists mainly of sediments of the Black Creek and Middendorf Formations. The Black Creek Formation is lagoonal to marine consisting of thinly laminated gray to black clay interlayered with gray to tan sands. A primary characteristic of Black Creek sediments in the subsurface is their high content of organic material, particularly lignitized wood. Shell material and glauconite are also common. The

Middendorf Formation is composed of a heterogeneous mix of fine to medium sand and silty clay beds, coarse channel sand, and thin laminated beds of sand and clay, all of nonmarine origin.

The Black Creek aquifer is not present in northwestern Wayne County (Winner and Coble, 1996). The altitude of the top of the aquifer ranges from less than $100 \mathrm{ft}$ above sea level in western Wayne County to about sea level in the eastern part of the county (Winner and Lyke, 1987). The top of the aquifer dips southeast about 6 feet per mile ( $\mathrm{ft} / \mathrm{mi}$ ) across the county.

The Black Creek aquifer thickens toward the southeast from a thickness of about $20 \mathrm{ft}$ at Grantham, an approximate average of $90 \mathrm{ft}(70-100 \mathrm{ft})$ at SJAFB (figs. 6 and 7), to about $250 \mathrm{ft}$ at Seven Springs. Winner and Lyke (1987) report the Black Creek aquifer in the central Coastal Plain has a high clay content and contains the least amount of sand of the Cretaceous aquifers. In Wayne County, the Black Creek aquifer contains less than 50 percent sand, except along its northwestern limit north of Goldsboro where it is composed of more than 50 percent sand. Estimates of hydraulic conductivity and average percentage of permeable material in the Black Creek aquifer are presented in table 3.

Recharge to the Black Creek aquifer in Wayne County and in the central Coastal Plain is in interstream areas wherever heads are greater in the overlying aquifer than in the Black Creek. Conversely, discharge from the Black Creek occurs wherever the head in the aquifer is greater than the head in the overlying aquifer. This condition occurs primarily in stream valleys.

The Black Creek confining unit, characterized by its black color, overlies the Black Creek aquifer everywhere the aquifer is present. The Black Creek confining unit is composed of clay, silty clay, and sandy clay beds (Winner and Lyke, 1987). The average thickness of the confining unit in Wayne County is about $16 \mathrm{ft}$ and is estimated to be about 8 to $20 \mathrm{ft}$ thick in the Goldsboro/SJAFB area. The Black Creek confining unit in Wayne County generally contains less than 10 percent sand, but may be as much as 25 percent (Winner and Lyke, 1987). Interbedded sands range in thickness at SJAFB from $6 \mathrm{ft}$ to almost $40 \mathrm{ft}$.

The Black Creek aquifer and confining unit were mapped by Winner and Lyke (1987) as missing along the Neuse River east of SJAFB. There, units are presumably cut into and eroded by the river, ex nosing sediments of the upper Cape Fear confining unit.

\section{Upper Cape Fear Aquifer and Confining Unit}

The upper Cape Fear aquifer is composed of sediments of the Cape Fear Formation that has been mapped throughout Wayne County (Winner and Coble, 1996). The altitude of the top of the aquifer ranges from about $50 \mathrm{ft}$ above sea level in the western part of Wayne County to about $200 \mathrm{ft}$ below sea level in the eastern part of the county (Winner and Lyke, 1987).

The upper Cape Fear aquifer thickens toward the southeast from a minimum observed thickness of $11 \mathrm{ft}$ near Saulston to $114 \mathrm{ft}$ at Cliffs of the Neuse State Park (fig. 1; Winner and Lyke, 1987). At SJAFB, the thickness of the aquifer is estimated to range from 10 to $60 \mathrm{ft}$ (figs. 6 and 7). The percentage of sand in the aquifer averages 62 percent (from 12 of 13 well-log observations, table 1) in Wayne County, but may be as much as 90 percent (Winner and Lyke, 1987).

Estimates of hydraulic conductivity and average percentage of permeable material in the upper Cape Fear aquifer are presented in table 3. Crystalline bedrock occurs immediately below the upper Cape Fear aquifer and is not considered as a source of water at SJAFB.

The upper Cape Fear confining unit is composed primarily of yellow to red clay and silt, and over'ies the upper Cape Fear aquifer (interbedded sand and clay layers that average 10 to $15 \mathrm{ft}$ thick) where the aquifer is present. Winner and Lyke (1987) report the uoper Cape Fear confining unit to be less than $25 \mathrm{ft}$ thick in the eastern half of Wayne County and less than $50 \mathrm{ft}$ thick in the western half. Sections A-A' and B-B' 
(figs. 6 and 7) show the upper Cape Fear confining unit to be as much as $40 \mathrm{ft}$ thick at SJAFB. The upper Cape Fear confining unit averages 18 percent sand based on observations from 12 of 13 wells (table 1) throughout Wayne County; however, Winner and Lyke (1987) estimated that the unit contained less then 10 percent sand at SJAFB.

\section{GROUND-WATER RESOURCES}

The primary sources of ground water for municipal and industrial water-supply systems in the SJAFB/Wayne County area are the Black Creek and upper Cape Fear aquifers. The surficial aquifer may not furnish sufficient quantities of water for these purposes but can be used for relatively low-yield uses such as domestic supplies.

\section{Water Use}

A well field of as many as nine water-supply wells was established during World War II at the southern corner of the Air Base adjacent to the Neuse River. Between 1942 and the late 1950's, several wells also were drilled to replace these nine wells. Additional irrigation wells were constructed on the SJAFB golf course. The water-supply wells were drilled into basement rock at depths of from 150 to $190 \mathrm{ft}$. These wells were generally finished with two or more screened sections ranging in length from 5 to $30 \mathrm{ft}$ imbedded in a gravel pack extending from the bottom of the wells, near the basement-rock surface, to several feet above the top of the uppermost screen. According to well records, some of the screens are set within clay beds. Water is obtained from the Black Creek and upper Cape Fear aquifers. Recorded ground-water pumpage data in these Cretaceous aquifers show pumpage in million gallons per day to be 1.00 in 1942 , 1.08 in 1950, 1.16 in 1960, 0.83 in 1970, 0.92 in 1980 , and 0.77 in 1986 (Winner and Lyke, 1986).

The tested yield of these supply wells ranged from about 100 gallons per minute ( $\mathrm{gal} / \mathrm{min}$ ) to more than $700 \mathrm{gal} / \mathrm{min}$, with an average yield of about 375 $\mathrm{gal} / \mathrm{min}$. The specific capacity of the wells, when first constructed, ranged from about $2 \mathrm{gal} / \mathrm{min}$ per foot of drawdown to about $15 \mathrm{gal} / \mathrm{min}$ per foot. The most productive wells are located adjacent to the Neuse River.
Since the 1940's, SJAFB has incurred high longterm maintenance costs and excessive water-supply well replacement costs associated with the corrosive nature of the low $\mathrm{pH} / \mathrm{high}$ iron content of the ground water. The corrosion of pump assemblies and(or) clogging of well screens by iron and other mineral precipitates may have resulted in diminished well yields with time. Consequently, in the late 1980's, the entire SJAFB began using Wayne County public water supplies, and all water-supply wells located on the southern end of the Air Base have since been plugged and abandoned.

\section{Surficial Aquifer}

The surficial aquifer consists of sequences of interbedded clays and sands and silty sands. Several of these shallow clay layers are believed to be laterally discontinuous. Drillers' logs of several abandoned water-supply wells report 10-20 ft sections of clay in the surficial aquifer near the Neuse River. There are no other data to support this reported thickness of clay in the surficial aquifer beneath the Air Base. Winner and Lyke (1987) report the surficial aquifer to be approximately $40 \mathrm{ft}$ thick in the SJAFB area, with the thicker sequences located in the upland areas and thinner sequences located on the southern end near the Neuse River and near the mouth of Stoney Creek. Mapped thicknesses of the surficial aquifer in this report are about $20 \mathrm{ft}$. Wells open to the surficial aquifer in Wayne County yield less than $10 \mathrm{gal} / \mathrm{min}$ (Pusey, 1960).

A water-level surface map for the surficial aquifer was constructed from measured water levels in 62 shallow monitoring wells and piezometers (fig. 8, table 2). Only those data from wells with verified locations and altitudes were used to develop the map. Also, wells containing petroleum fuels were not measured for this map. Ground-water movement in the surficial aquifer is away from areas of high hydraulic head toward the Neuse River and Stoney Creek (fig. 3).

At a few of the monitoring wells, water-level measurements were not included in contoured results (fig. 8) because these measurements were not consistent with the general water-level trend elsewhere on the Air Base. There are not sufficient data to determine if the questionable readings are the result of local hydrogeologic conditions (screened in perched aquifer), placement of well screens in clay, compaction 


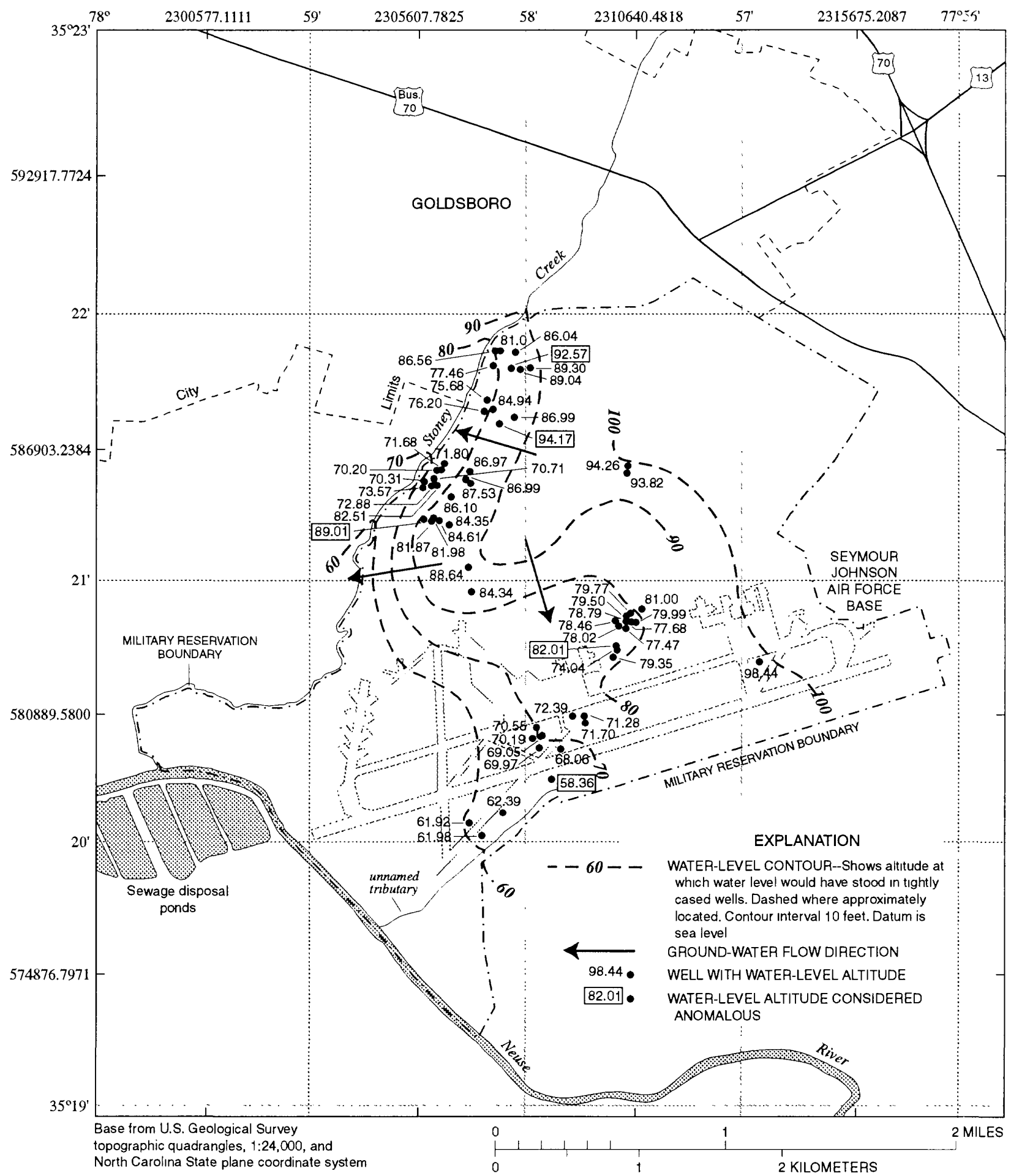

Figure 8. Water-level surface map for surficial aquifer at Seymour Johnson Air Force Base, June-July 1996. 
of soils and impervious cover associated with building or runway construction, some combination of these, or some yet unidentified reason.

\section{Black Creek Aquifer}

The Black Creek aquifer at SJAFB seems to be composed of two main sequences of sand in some places in addition to numerous thinner beds. These sand beds are separated by thin to moderately thick clay beds. Based on sparse data, the sand and clay beds do not appear to be laterally continuous for very great distances. The total thickness of the Black Creek aquifer ranges from about $45 \mathrm{ft}$ near the Neuse River to about $70 \mathrm{ft}$ (well SJCG-3, fig. 7) in the northeastern section of the Air Base.

The altitude of the top of the Black Creek aquifer (fig. 9) was estimated from available well log data from abandoned water-supply wells and golf course irrigation wells. The altitude of the top of the Black Creek aquifer also was estimated from the hydrogeologic sections between well picks. In several cases the only data available were from drillers' logs collected when the well was installed in the 1940's.

\section{Upper Cape Fear Aquifer}

The upper Cape Fear aquifer at SJAFB ranges in thickness from about 10 to $60 \mathrm{ft}$. The unit consists of a single 10-ft sand bed just north of the Air Base. Elsewhere, the aquifer contains multiple beds of sand and clay that are discontinuous in nature and thickest along the Neuse River. Few data are available to adequately characterize this aquifer at the Air Base.

\section{ADDITIONAL DATA NEEDS}

The shallow monitoring wells and several of the abandoned water-supply wells were of limited use in developing the hydrogeologic framework because of a combination of several factors. Most shallow monitoring wells were placed at similar depths, and the shallow monitoring well data files and several watersupply well files contained limited lithologic data and no borehole geophysical logs. Also, the available lithologic data were insufficient to show lateral correlation of clay and aquifer layers within the underlying Cretaceous units.

A more detailed hydrologic and hydrogeologic study of the surficial, Black Creek, and upper Cape Fear aquifers is needed to clearly establish relations between these aquifers at SJAFB. Most of the hydrogeologic information used for this study was gathered from investigations of individual sites. There appears to be no information available on how these sites may relate to each other or to the underlying aquifer systems. Almost all the monitoring wells placed at these sites are screened in the surficial aquifer. There appears to be some indication of perched water tables on the central part of the Air Base, but there are not sufficient hydrogeologic data to accurately identify those areas.

Except for the golf course irrigation wells, there are no known accessible Air Base wells that penetrate the Black Creek or the upper Cape Fear aquifer. All former water-supply wells located on the southern end of the Air Base have been abandoned and are no longer accessible. Therefore, it is not possible to measure separate water levels in the Black Creek or the upper Cape Fear aquifer. Existing well files indicate that there are limited lithologic data from the golf course wells and limited historical information from drillers' logs from most of the water-supply wells. Water-level measurements in individual aquifers would be helpful in determining head differences between the aquifers and for estimating the potential for movement of water from the surficial aquifer into the Black Creek and upper Cape Fear aquifers. Well clusters with wells screened in the surficial, Black Creek, and upper Cape Fear aquifers would be useful in resolving the question about hydraulic heads.

Additional stratigraphic test wells that penetrate. the surficial, Black Creek, and upper Cape Fear aquifers are needed to provide hydrogeologic data to develop a comprehensive hydrogeologic framework of the Air Base. Borehole-geophysical and boreholelithologic data should be collected from these test wells. It would be helpful to place stratigraphic test wells at five or more areas of the Air Base including the southwest, southeast, northwest, northeast, and central parts of SJAFB. 


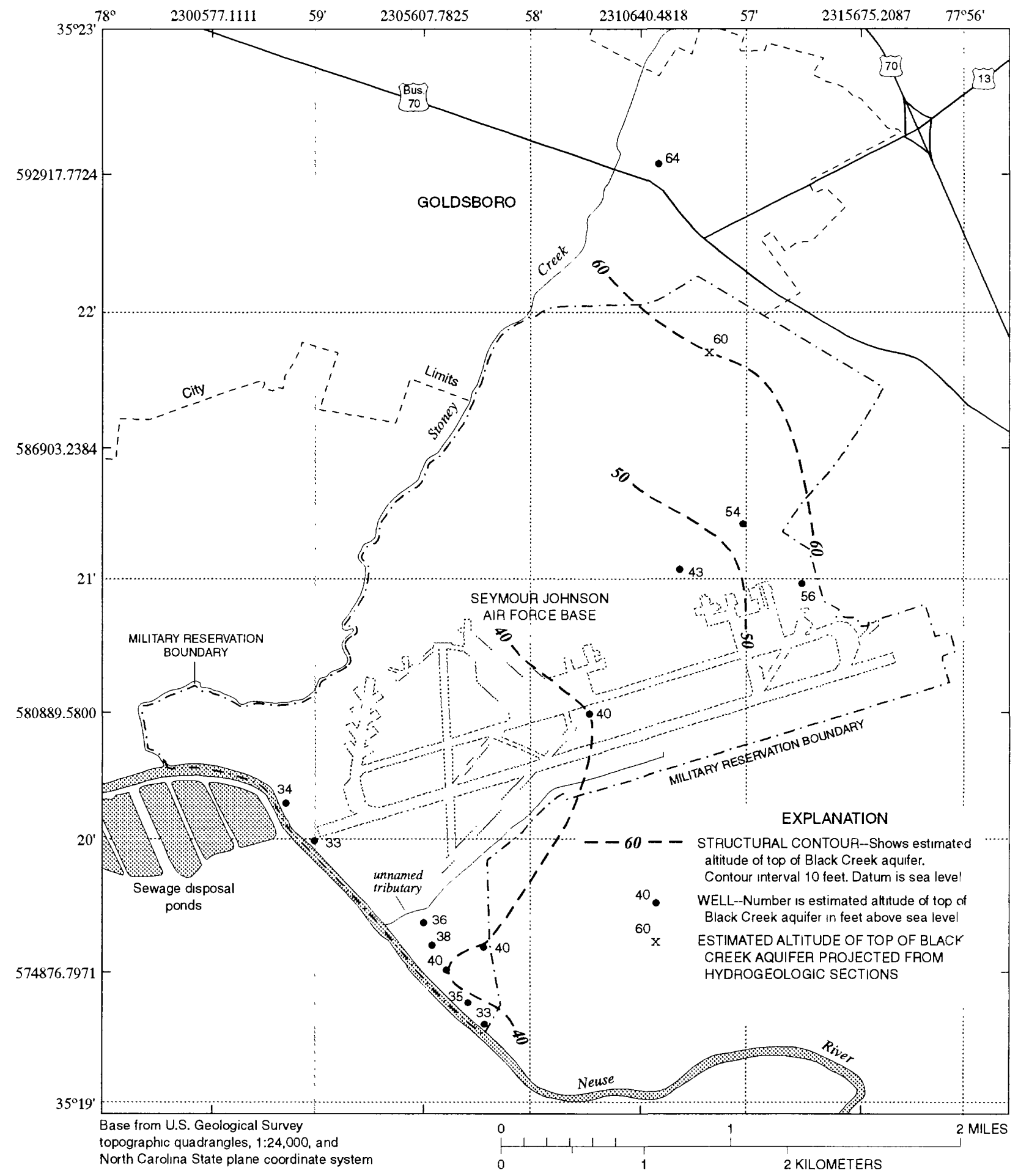

Figure 9. Estimated altitude of top of Black Creek aquifer in northeast part of Seymour Johnson Air Force Base, North Carolina. 


\section{SUMMARY}

Seymour Johnson Air Force Base is located in Wayne County within the inner Coastal Plain of North Carolina. A preliminary study of the hydrogeologic framework of the Air Base was conducted to develop a better understanding of the surficial, Black Creek, and upper Cape Fear aquifers. Data used included available hydrologic information from the well files and records from the Air Base, City of Goldsboro and Wayne County, and the North Carolina Geological Survey. The U.S. Geological Survey collected geophysical well logs from selected wells on the Air Base.

Hydrogeologic units in Wayne County and at SJAFB were mapped using a combination of borehole geophysical logs, lithologic logs, and historical drillers' logs. The results of previous studies also were utilized to help determine depth and thickness of the various hydrogeologic units.

Two hydrogeologic sections of the SJAFB area were developed from the available hydrogeologic data. The aquifers delineated on these sections include the surficial, Black Creek, and upper Cape Fear aquifers. These two sections map the hydrogeology along two traverses at SJAFB. Both hydrogeologic sections are tied together through a common well on the Air Base.

The surficial aquifer at SJAFB is the uppermost aquifer and consists of sand, clay, sandy clay, and silty clay. The surficial aquifer appears to have greater variability of clays and sands than the underlying Black Creek and upper Cape Fear aquifers. The surficial aquifer at SJAFB ranges in thickness from about $10 \mathrm{ft}$ near the Neuse River to approximately $20 \mathrm{ft}$ near the central part of the Air Base.

Recharge to the surficial aquifer is by infiltration from rainfall. The surficial aquifer transmits water laterally to the Neuse River and Stoney Creek, and transmits water vertically to the Black Creek and upper Cape Fear aquifers. Recharge to the surficial aquifer depends on how rapidly rainfall can infiltrate into the aquifer.

A surficial aquifer water-level map was constructed from measured water levels in 62 shallow monitoring wells screened in the surficial aquifer. Only those data from wells with verified locations and altitudes, or that contained no fuel comtamination, were used to develop this map. The results indicate that general ground-water movement in the surficial aquifer is away from areas of high hydraulic head toward the Neuse River and Stoney Creek.
The Black Creek aquifer under the Air Base contains sequences of interbedded sands and clays. The Black Creek aquifer and overlying confining unit are estimated from well-log data to be approximately $100 \mathrm{ft}$ thick under the Air Base. The overlying Black Creek confining unit is characterized by its black color and interbedded sand lenses. This confining unit ranges in thickness at SJAFB from less than $8 \mathrm{ft}$ to more than $20 \mathrm{ft}$. Interbedded sands range in thickness at SJAFB from $6 \mathrm{ft}$ to almost $40 \mathrm{ft}$.

The altitude of the top of the Black Creek aquifer was estimated from geophysical well logs, lithologic logs, or historical drillers' logs, for those few areas of the Air Base where water-supply wells or irrigation wells penetrate the Black Creek and upper Cape Fear aquifers. There are insufficient data to extend the estimated top of the Black Creek aquifer to other parts of the Air Base.

The upper Cape Fear aquifer and confining unit generally occur at depths greater than $80 \mathrm{ft}$ below land surface and are estimated to range in thickness from 50 to about $70 \mathrm{ft}$ under SJAFB. The upper Cape Fear confining unit varies in color from yellow to red and is underlain by interbedded sand and clay layers that average 10 to $15 \mathrm{ft}$ thick. Clay and underlying sand deposited at the bottom of this aquifer are believed to be part of the lower Cape Fear confining unit and aquifer, respectively.

The results in this report are considered preliminary. Additional monitoring well clusters with wells screened in the surficial aquifer and the Black Creek aquifer, and additional stratigraphic test wells are needed to adequately delineate the surficial, Black Creek, and upper Cape Fear aquifers that underlie SJAFB.

\section{REFERENCES}

Brown, P.M., Miller, J.A., and Swain, F.M., 1972, Structural and stratigraphic framework and spatial distribution of permeability of the Atlantic Coastal Plain, New York to North Carolina: U.S. Geological Survey Professional Paper 796, $79 \mathrm{p}$.

Eimers, J.L., Lyke, W.L., and Brockman, A.R., 1990, Simulation of ground-water flow in aquifers in Cretaceous rocks in the central Coastal Plain, North Carolina: U. S. Geological Survey WaterResources Investigations Report 89-4153, $101 \mathrm{p}$. 
IMS, 1995, Chemical data acquisition plan for soil sampling and monitoring well installation program site investigation POL Storage Area (Sites SD-02, SD-03, ST-05) and SAC Fuel Hydrant System (Site SS-12), Seymour Johnson Air Force Base, Goldsboro, N.C., Contract No. DACW45-9-D-004 9, Delivery Order No. 00001.

Lyke, W.L., and Winner, M.D., Jr., 1986, Altitude of basement surface in the central Coastal Plain of North Carolina: U.S. Geological Survey WaterResources Investigations Report 86-4082, 2 sheets.

Maxey, G.B., 1964, Hydrostratigraphic units: Journal of Hydrology, v. 2, no. 2, p. 124-129.

Pusey, R.D., 1960, Geology and ground water in the Goldsboro area, North Carolina: North Carolina Department of Water Resources, Ground-Water Bulletin 2, $77 \mathrm{p}$.
Tant, P.L., Byrd, H.J., and Horton, R.E., 1974, General soil map of North Carolina: U.S. Soil Conservation Service, scale $1: 1,000,000$.

Winner, M.D., Jr., 1976, Ground-water resources of Wilson County, North Carolina: U.S. Geological Survey WaterResources Investigations Report 76-60, 85 p.

Winner, M.D., Jr., and Coble, R.W., 1996, Hydroge ologic framework of the North Carolina Coastal Plair: U.S. Geological Survey Professional Paper 1401-I, 106 p.

Winner, M.D., Jr., and Lyke, W.L., 1986, History of groundwater pumpage and water-level decline in the Black Creek and upper Cape Fear aquifers of the central Coastal Plain of North Carolina: U.S. Geological Survey Water-Resources Investigations Report 86-4168, $21 \mathrm{p}$.

1987, Aquifers in Cretaceous rocks of the cer'ral Coastal Plain of North Carolina: U.S. Geological Survey Water-Resources Investigations Report $87-4178,71 \mathrm{p}$. 
Table 1. Records of selected water-supply and stratigraphic test wells in the Seymour Johnson Air Force Base area, North Carolina

[ft, feet; USGS, U.S. Geological Survey; —, no data; G, geophysical; GR, gamma ray; DL, driller's log; NCGS, North Carolina Geological Survey; E, electric; L, lithologic]

\begin{tabular}{lcccccc}
\hline $\begin{array}{c}\text { Well } \\
\text { identfication } \\
\text { (fig. 3) }\end{array}$ & $\begin{array}{c}\text { State plane } \\
\text { X-coordlnate }\end{array}$ & $\begin{array}{c}\text { State plane } \\
\text { Y-coordinate }\end{array}$ & $\begin{array}{c}\text { Measuring } \\
\text { point } \\
\text { altitude } \\
\text { (ft) }\end{array}$ & $\begin{array}{c}\text { Record } \\
\text { by }\end{array}$ & $\begin{array}{c}\text { Hydrogeo- } \\
\text { logic } \\
\text { section }\end{array}$ & $\begin{array}{c}\text { Geophysical/ } \\
\text { lithologic } \\
\text { logs }\end{array}$ \\
\hline MW1503D & 2309486.500 & 580637.875 & 84.40 & USGS & - & G(GR) \\
SJGC-2 & 2311414.750 & 584078.375 & 66.0 & USGS & B-B' & G(GR) \\
SJGC-3 & 2312976.000 & 585038.062 & 67.0 & USGS & B-B' & G(GR) \\
SJGC-7 & 2314399.000 & 583547.750 & 68.0 & USGS & - & G(GR) \\
SJW-2 & 2305722.500 & 575783.375 & 61.0 & USGS & A-A' & DL \\
SJW-4 & 2307643.878 & 574286.759 & 61.0 & USGS & A-A' & DL \\
SJW-5 & 2303217.500 & 577678.500 & 61.0 & USGS & A-A' & DL \\
SJW-6 & 2308221.222 & 575091.172 & 61.0 & USGS & A-A' & DL \\
SJW-7 & 2305607.744 & 574494.969 & 61.0 & USGS & A-A' & DL \\
SJW-8 & 2305309.402 & 575677.998 & 61.0 & USGS & A-A' & DL \\
WY-T-1-83 & 2307234.750 & 573777.000 & 59.0 & NCGS & A-A', B-B' & G(GR) \\
WY-T-1-84 & 2311258.500 & 593028.188 & 118.00 & NCGS & B-B' & G(GR) \\
WY-T-3-84 & 2302545.500 & 578581.562 & 66.0 & NCGS & B-B' & G(GR, E); L \\
\hline
\end{tabular}


Table 2. Records of selected monitoring wells in the Seymour Johnson Air Force Base area, North Carolina [ft, feet; COE, U.S. Army Corps of Engineers; USGS, U.S. Geological Survey; —, no data]

\begin{tabular}{|c|c|c|c|c|c|c|c|c|}
\hline \multirow{2}{*}{$\begin{array}{c}\text { Well } \\
\text { identification } \\
\text { (fig. } 3 \text { ) }\end{array}$} & \multirow{2}{*}{$\begin{array}{l}\text { State plane } \\
\text { X-coordinate }\end{array}$} & \multirow{2}{*}{$\begin{array}{l}\text { State plane } \\
\text { Y-coordinate }\end{array}$} & \multirow{2}{*}{$\begin{array}{l}\text { Measuring } \\
\text { point } \\
\text { altitude } \\
\text { (ft) }\end{array}$} & \multirow{2}{*}{$\begin{array}{l}\text { Water level, } \\
\text { below } \\
\text { measuring } \\
\text { point } \\
\text { (ft) }\end{array}$} & \multirow{2}{*}{$\begin{array}{l}\text { Water- } \\
\text { level } \\
\text { altitude } \\
\text { (ft) }\end{array}$} & \multicolumn{3}{|c|}{ Water-level measuremert } \\
\hline & & & & & & Date & Time & By \\
\hline MW101A & 2305469.000 & 585239.938 & 87.97 & 6.88 & 81.09 & $7 / 10 / 96$ & 1129 & $\mathrm{COE}$ \\
\hline MW1101 & 2313568.750 & 581950.375 & 103.56 & 5.12 & 98.44 & $6 / 28 / 96$ & 1423 & USGS \\
\hline MW1201 & 2310153.250 & 582119.688 & 85.37 & 3.36 & 82.01 & $7 / 11 / 96$ & 0835 & $\mathrm{COE}$ \\
\hline MW1202 & 2310172.250 & 582087.812 & 86.64 & 12.60 & 74.04 & $7 / 11 / 96$ & 0847 & $\mathrm{COE}$ \\
\hline MW1203 & 2310094.000 & 581905.750 & 91.38 & 12.03 & 79.35 & $7 / 11 / 96$ & 0902 & $\mathrm{COE}$ \\
\hline MW1302 & 2310357.500 & 586205.125 & 106.83 & 13.01 & 93.82 & $7 / 11 / 96$ & 0756 & $\mathrm{COE}$ \\
\hline MW1303 & 2310425.250 & 586325.500 & 106.32 & 12.06 & 94.26 & $7 / 11 / 96$ & 0807 & $\mathrm{COE}$ \\
\hline MW1417 & 2306969.000 & 583350.000 & 88.37 & 4.03 & 84.34 & $7 / 03 / 96$ & - & USGS \\
\hline MW1501 & 2309208.750 & 580679.438 & 84.63 & 12.24 & 72.39 & $6 / 28 / 96$ & 1821 & USGS \\
\hline MW1503D & 2309486.500 & 580637.875 & 84.40 & 13.12 & 71.28 & $6 / 28 / 96$ & 1716 & USGS \\
\hline MW1504 & 2309503.500 & 580536.938 & 84.08 & 12.38 & 71.70 & $7 / 03 / 96$ & - & USGS \\
\hline MW1505 & 2308325.000 & 580066.000 & 76.68 & 6.71 & 69.97 & $6 / 28 / 96$ & 1604 & USGS \\
\hline MW1506 & 2308731.750 & 579153.938 & 74.68 & 16.32 & 58.36 & $6 / 28 / 96$ & 1004 & USGS \\
\hline MW1507 & 2308863.500 & 579929.750 & 76.94 & 8.88 & 68.06 & $7 / 03 / 96$ & - & USGS \\
\hline MW1509D & 2308420.000 & 580293.000 & 78.77 & 9.72 & 69.05 & $6 / 28 / 96$ & 1611 & USGS \\
\hline MW1511 & 2308298.000 & 580458.000 & 80.77 & 10.22 & 70.55 & $6 / 28 / 96$ & 1545 & USGS \\
\hline MW 1512 & 2308150.000 & 580201.000 & 76.56 & 6.37 & 70.19 & $6 / 28 / 96$ & 1555 & USGS \\
\hline MW203 & 2305575.500 & 586041.438 & 73.33 & 3.02 & 70.31 & $7 / 10 / 96$ & 0843 & $\mathrm{COE}$ \\
\hline MW204 & 2305741.750 & 585940.125 & 77.98 & 4.41 & 73.57 & $7 / 09 / 96$ & 1042 & $\mathrm{COE}$ \\
\hline MW40 & 2306057.750 & 585113.250 & 93.74 & 9.39 & 84.35 & $7 / 09 / 96$ & 1637 & $\mathrm{COE}$ \\
\hline MW401 & 2307717.000 & 588573.938 & 105.87 & 13.30 & 92.57 & $7 / 10 / 96$ & 1414 & $\mathrm{COE}$ \\
\hline MW402 & 2307924.000 & 588565.250 & 98.85 & 9.81 & 89.04 & $7 / 10 / 96$ & 1426 & $\mathrm{COE}$ \\
\hline MW405 & 2307299.250 & 588678.438 & 89.03 & 11.57 & 77.46 & $7 / 10 / 96$ & 1537 & $\mathrm{COE}$ \\
\hline MW406 & 2307447.750 & 589018.125 & 95.40 & 14.40 & 81.00 & $7 / 10 / 96$ & 1454 & $\mathrm{COE}$ \\
\hline MW41 & 2305646.000 & 585172.750 & 91.52 & 9.65 & 81.87 & $7 / 09 / 96$ & 1608 & $\mathrm{COE}$ \\
\hline MW42 & 2305689.250 & 585212.000 & 93.69 & 11.71 & 81.98 & $7 / 09 / 96$ & 1557 & $\mathrm{COE}$ \\
\hline MW43 & 2306708.500 & 585950.000 & 104.02 & 17.48 & 86.54 & $7 / 09 / 96$ & 1521 & $\mathrm{COE}$ \\
\hline MW46 & 2305782.250 & 586084.312 & 75.84 & 5.13 & 70.71 & $7 / 09 / 96$ & 0925 & $\mathrm{COE}$ \\
\hline MW47 & 2306024.250 & 586429.688 & 76.76 & 4.96 & 71.80 & $7 / 10 / 96$ & 1013 & $\mathrm{COE}$ \\
\hline MW48 & 2305915.000 & 586255.313 & 75.52 & 3.84 & 71.68 & $7 / 09 / 96$ & 1130 & $\mathrm{COE}$ \\
\hline MW49 & 2305927.750 & 586274.188 & 76.78 & 6.06 & 70.72 & $7 / 09 / 96$ & 1119 & $\mathrm{COE}$ \\
\hline MW50 & 2308156.750 & 588575.875 & 100.80 & 11.50 & 89.30 & $7 / 10 / 96$ & 1357 & $\mathrm{COE}$ \\
\hline MW501 & 2307342.000 & 587532.188 & 101.71 & 16.77 & 84.94 & $7 / 10 / 96$ & 1700 & $\mathrm{COE}$ \\
\hline MW502 & 2307485.500 & 587213.750 & 97.50 & 3.33 & 94.17 & $7 / 10 / 96$ & 1809 & $\mathrm{COE}$ \\
\hline
\end{tabular}


Table 2. Records of selected monitoring wells in the Seymour Johnson Air Force Base area, North Carolina-Continued [ft, feet; COE, U.S. Army Corps of Engineers; USGS, U.S. Geological Survey; —, no data]

\begin{tabular}{|c|c|c|c|c|c|c|c|c|}
\hline \multirow{2}{*}{$\begin{array}{c}\text { Well } \\
\text { identification } \\
\text { (fig. 3) }\end{array}$} & \multirow{2}{*}{$\begin{array}{l}\text { State plane } \\
\text { X-coordinate }\end{array}$} & \multirow{2}{*}{$\begin{array}{l}\text { State plane } \\
\text { Y-coordinate }\end{array}$} & \multirow{2}{*}{$\begin{array}{l}\text { Measuring } \\
\text { point } \\
\text { altltude } \\
\text { (ft) }\end{array}$} & \multirow{2}{*}{$\begin{array}{c}\text { Water level, } \\
\text { below } \\
\text { measuring } \\
\text { point } \\
\text { (ft) }\end{array}$} & \multirow{2}{*}{$\begin{array}{l}\text { Water- } \\
\text { level } \\
\text { altitude } \\
\text { (ft) }\end{array}$} & \multicolumn{3}{|c|}{ Water-level measurement } \\
\hline & & & & & & Date & Time & By \\
\hline MW503 & 2307120.750 & 587527.000 & 82.01 & 5.81 & 76.20 & $7 / 10 / 96$ & 1830 & $\mathrm{COE}$ \\
\hline MW504 & 2307179.250 & 587822.625 & 87.57 & 11.89 & 75.68 & $7 / 10 / 96$ & 1637 & COE \\
\hline MW505 & 2307822.750 & 587384.000 & 104.85 & 17.86 & 86.99 & $7 / 10 / 96$ & 1639 & $\mathrm{COE}$ \\
\hline MWPOL1 & 2307049.255 & 577993.322 & 69.31 & 7.33 & 61.98 & $6 / 28 / 96$ & 1023 & USGS \\
\hline MWPOL2 & 2306874.392 & 578083.853 & 69.70 & 7.78 & 61.92 & $6 / 28 / 96$ & 1030 & USGS \\
\hline MWPOL3 & 2307544.763 & 578507.026 & 70.42 & 8.03 & 62.39 & $6 / 28 / 96$ & 1041 & USGS \\
\hline MWPTW1 & 2306847.000 & 584072.000 & 95.40 & 7.36 & 88.04 & $7 / 03 / 96$ & - & USGS \\
\hline MWRMS-1 & 2307770.612 & 585970.864 & 107.67 & 16.11 & 91.56 & $7 / 03 / 96$ & - & USGS \\
\hline MWRMS-2 & 2307711.879 & 585899.799 & 108.26 & 16.54 & 91.72 & $7 / 03 / 96$ & - & USGS \\
\hline MWRMS-3 & 2307814.429 & 585849.475 & 108.76 & 16.79 & 91.97 & $7 / 03 / 96$ & - & USGS \\
\hline MWTOW1 & 2310232.750 & 582569.625 & 87.04 & 9.02 & 78.02 & $7 / 03 / 96$ & - & USGS \\
\hline MWTOW2 & 2310141.250 & 582675.875 & 83.37 & 4.91 & 78.46 & $7 / 03 / 96$ & - & USGS \\
\hline MWTOW3 & 2310318.750 & 582736.375 & 95.13 & 16.34 & 78.79 & $7 / 03 / 96$ & - & USGS \\
\hline MWTOW4 & 2310368.000 & 582853.125 & 94.87 & 14.88 & 79.99 & $7 / 03 / 96$ & 一 & USGS \\
\hline MWTOW4D & 2310459.194 & 582907.829 & 94.76 & 14.99 & 79.77 & $7 / 03 / 96$ & - & USGS \\
\hline MWTOW5 & 2310427.089 & 582725.459 & 96.56 & 18.88 & 77.68 & $7 / 03 / 96$ & - & USGS \\
\hline MWTOW6 & 2310365.236 & 582562.603 & 86.80 & 9.33 & 77.47 & $7 / 03 / 96$ & - & USGS \\
\hline MWTOW7 & 2310329.579 & 582855.539 & 93.62 & 14.12 & 79.50 & $7 / 03 / 96$ & - & USGS \\
\hline MWTOW8 & 2310729.912 & 582997.971 & 103.00 & 22.00 & 81.00 & $7 / 03 / 96$ & - & USGS \\
\hline PZ103 & 2305842.750 & 585195.688 & 95.18 & 10.54 & 84.64 & $7 / 09 / 96$ & 1542 & $\mathrm{COE}$ \\
\hline PZ206 & 2305836.000 & 586028.000 & 78.13 & 5.25 & 72.88 & $7 / 09 / 96$ & 0920 & $\mathrm{COE}$ \\
\hline PZ207 & 2305898.000 & 585924.000 & 95.14 & 12.63 & 82.51 & $7 / 09 / 96$ & 1345 & COE \\
\hline PZ208 & 2306181.500 & 585711.688 & 102.08 & 15.98 & 86.10 & $7 / 09 / 96$ & 1408 & $\mathrm{COE}$ \\
\hline PZ209 & 2306522.000 & 586083.938 & 101.04 & 14.05 & 86.99 & $7 / 09 / 96$ & 1426 & $\mathrm{COE}$ \\
\hline PZ210 & 2306632.250 & 586270.125 & 103.07 & 16.04 & 86.97 & $7 / 09 / 96$ & 1440 & COE \\
\hline PZ211 & 2306633.250 & 585996.812 & 103.89 & 16.36 & 87.53 & $7 / 09 / 96$ & 1510 & $\mathrm{COE}$ \\
\hline PZ407 & 2307818.000 & 588942.938 & 101.02 & 14.98 & 86.04 & $7 / 10 / 96$ & 1441 & $\mathrm{COE}$ \\
\hline PZ408 & 2307330.000 & 589002.938 & 93.41 & 6.85 & 86.56 & $7 / 10 / 96$ & 1610 & $\mathrm{COE}$ \\
\hline
\end{tabular}

